\title{
Endoscopic submucosal dissection of 301 large colorectal neoplasias: outcome and learning curve from a specialized center in Europe
}

\section{다(1) $(2)$}

\author{
Authors \\ Carl-Fredrik Rönnow ${ }^{1}$, Noriya Uedo ${ }^{2}$, Ervin Toth ${ }^{3}$, Henrik Thorlacius ${ }^{1}$
}

Institutions

1 Department of Clinical Sciences, Surgery, Skåne University Hospital, Lund University, Malmö, Sweden

2 Department of Gastrointestinal Oncology, Osaka International Cancer Institute, Osaka, Japan

3 Department of Clinical Sciences, Gastroenterology, Skåne University Hospital, Lund University, Malmö, Sweden

submitted 23.4.2018

accepted after revision 31.7.2018

\author{
Bibliography \\ DOI https://doi.org/10.1055/a-0733-3668 | \\ Endoscopy International Open 2018; 06: E1340-E1348 \\ (c) Georg Thieme Verlag KG Stuttgart · New York \\ ISSN 2364-3722
}

Corresponding author

Henrik Thorlacius, MD, PhD, Department of Clinical

Sciences, Malmö, Section of Surgery, Skåne University

Hospital, Lund University, S-205 02 Malmö, Sweden

Fax: +46-40-336207

henrik.thorlacius@med.lu.se

\section{ABSTRACT}

Background and study aims Endoscopic submucosal dissection (ESD) allows en bloc resection of large colorectal lesions but ESD experience is limited outside Asia. This study evaluated implementation of ESD in the treatment of colorectal neoplasia in a Western center.

Patients and methods Three hundred and one cases of colorectal ESD (173 rectal and 128 colonic lesions) were retrospectively evaluated in terms of outcome, learning curve and complications.

Results Median size was $4 \mathrm{~cm}$ (range $1-12.5)$. En bloc resection was achieved in 241 cases amounting to an en bloc resection rate of $80 \%$. R0 resection was accomplished in 207 cases (69\%), RX and R1 were attained in $83(27 \%)$ and 11 (4\%) cases, respectively. Median time was 98 min (range $10-588$ ) and median proficiency was $7.2 \mathrm{~cm}^{2} / \mathrm{h}$. Complications occurred in 24 patients ( $8 \%$ ) divided into 12 immediate perforations, five delayed perforations, one immediate bleeding and six delayed bleedings. Six patients $(2 \%)$, all with proximal lesions, had emergency surgery. Two hundred and four patients were followed up endoscopically and median follow-up time was 13 months (range 3-53) revealing seven recurrences (3\%). En bloc rate improved gradually from $60 \%$ during the first period to $98 \%$ during the last period. ESD proficiency significantly improved between the first study period $\left(3.6 \mathrm{~cm}^{2} / \mathrm{h}\right)$ and the last study period $\left(10.8 \mathrm{~cm}^{2} / \mathrm{h}\right)$.

Conclusions This study represents the largest material on colorectal ESD in the west and shows that colorectal ESD can be implemented in clinical routine in western countries after appropriate training and achieve a high rate of en bloc and $\mathrm{R} 0$ resection with a concomitant low incidence of complications. ESD of proximal colonic lesions should be attempted with caution during the learning curve because of higher risk of complications.

\section{Introduction}

Endoscopic removal of neoplasia in the colon and rectum has been proven to reduce incidence and mortality of colorectal cancer (CRC) [1]. It is generally held that pedunculated colorectal lesions can be resected with snare polypectomy irrespective of polyp size [2]. Non-pedunculated polyps in the colon and rectum are more challenging to remove and endoscopic mucosal resection (EMR) has become standard method for resecting flat and sessile lesions either en bloc (lesion size $<2 \mathrm{~cm}$ ) or piece meal (lesions size $>2 \mathrm{~cm}$ ) [3-5]. It is well known that risk of submucosal invasive cancer increases in parallel to polyp size. In fact, incidence of malignant infiltration in colorectal lesions larger than $2 \mathrm{~cm}$ is higher than $10 \%$ [6-9]. Piecemeal resection is not only associated with a risk of incomplete resection and tumor recurrence but also a non-conclusive pathological evaluation in terms of tumor resection margins, which in cases of submucosal invasive cancer can result in unnecessary surgery [10]. 

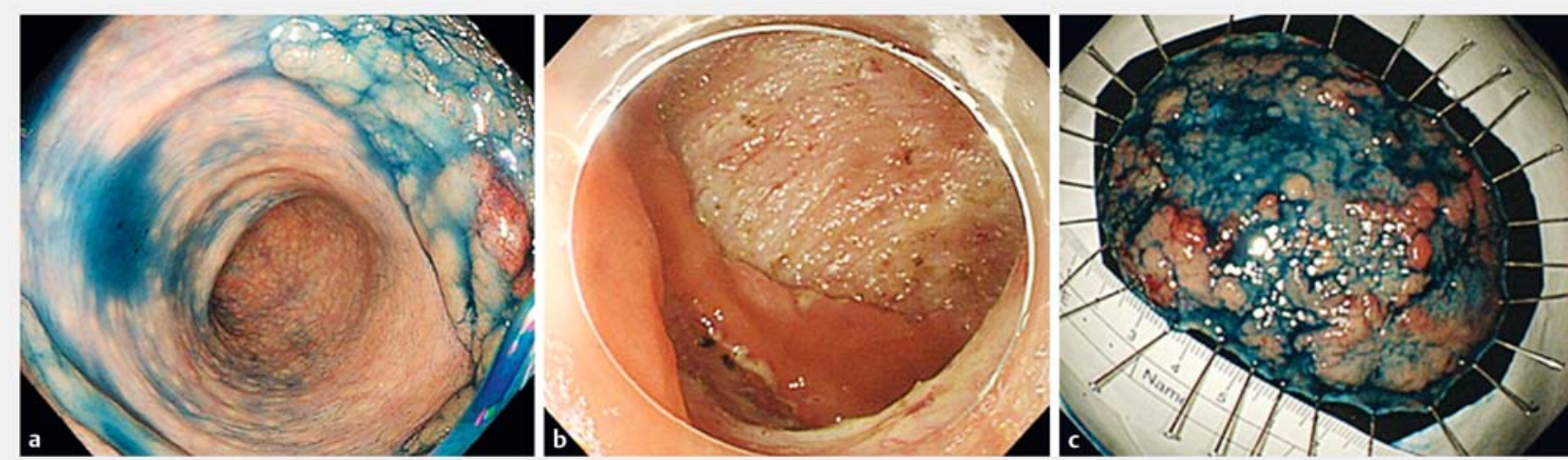

- Fig. 1 ESD procedure. a A large $(90 \times 60 \mathrm{~mm})$, flat (Paris classification Ila), sigmoid lesion as seen with normal endoscopic view with indigo carmine staining prior to resection. b The post-ESD wound covering $80 \%$ of the circumference. $\mathbf{c}$ The specimen, resected en bloc, pinned on to a hard plate.

Knowing that pre-resection diagnosis of submucosal invasion is notoriously difficult, en bloc resection is recommended for removal of large colorectal lesions [11-13].

Endoscopic submucosal dissection (ESD) was developed in Japan to avoid piecemeal resection and allows en bloc resection of large gastric and colorectal neoplasias. As of today, ESD has been implemented as standard treatment of large gastrointestinal lesions in many Asian countries and the efficacy has been well documented in numerous reports $[6,11,14-15]$. However, dissemination of ESD in western countries has been slow and only a handful centers in Europe have established comprehensive and proficient ESD programs. Major challenges for implementing ESD in western countries comprise a long learning curve, high risk of complications, lack of structured training programs, few suitable starting cases in the stomach, and lack of experts [16-21]. Although there has been an increase in the number of published reports on colorectal ESD from western countries the majority of these are relatively small containing less than 100 cases with few exceptions [8-9,22-23].

Herein, we present the largest material on colorectal ESD in the west, to our knowledge, including outcome, complications and learning curve.

\section{Patients and methods}

\section{Patients and tumors}

From January 2013 to November 2017, 872 patients with large $(>2 \mathrm{~cm})$, non-pedunculated or recurrent colorectal lesions referred for ESD underwent endoscopic resection at our tertiary colonoscopy center at Skåne University Hospital in Malmö, Sweden. Lesions were thoroughly investigated by use of topical administration of $0.4 \%$ indigo carmine and narrowband imaging (NBI), in addition to white light to detect signs of invasive cancer and to assess the most optimal endoscopic resection technique. In general, EMR was selected for lesions smaller than $3 \mathrm{~cm}$ with low suspicion of submucosal invasion. ESD was chosen for lesions larger than $3 \mathrm{~cm}$ or lesions with suspicion of submucosal invasion. Five hundred and thirty-five lesions were resected with either EMR or underwater EMR and 337 lesions were resected with ESD. We excluded all 36 malignant lesions from this study solely since they have been reported previously [24]. In the current study, we retrospectively included and reviewed 301 colorectal ESD cases without submucosal invasion. Paris classification was used to define macroscopic appearance of the tumors [25]. Localization of lesions was divided as follows: rectum, distal colon (sigmoid and descending colon) and proximal colon (cecum, ascending and transverse colon).

\section{Colorectal ESD}

All patients underwent colonic cleansing with polyethylene glycol and were given scopolamine butyl bromide or glucagon to reduce bowel movements as well as sedatives and analgesic. Conventional video endoscope (GIF-H180) and CF-H180AI, Olympus, Hamburg, Germany) with a disposable distal hood (D-201-11804 or D-201-15004, Olympus) attached to the tip of the endoscope was employed. Carbon dioxide was utilized for insufflation. For electrical cutting and coagulation VIO 300 D (ERBE Elektromedizin, Tübingen, Germany) was used as a power source (Cut: Endocut 1 effect 2; Forced coagulation: Effect 2, 40W; Soft coagulation: Effect 5, 60 W). ESD was carried out in a standardized manner using a Flush-knife (Fujifilm Europe $\mathrm{GmbH}$, Düsseldorf, Germany) connected to a water jet pump, as described in detail previously ( $\triangleright$ Fig. 1) [26]. Hyaluronate sodium solution $(0.4 \%$, Sigmavisc, Hyaltech Ltd, Livingston, UK) was used to lift the mucosal layer. Hemostatic forceps (Coagrasper, FD-411UR, Olympus) was used to prevent and treat bleeding. Resected specimens were retrieved using grasping forceps (FG-47L-1; Olympus) or a retrieval device (Roth Net, US Endoscopy, Mentor Ohio, United States). Specimens were measured after being pinned onto a hard plate and then submerged in $10 \%$ formalin. Lesion area was calculated using the formula $A=a b \pi$, where $a$ is half the diameter of the major diameter and $b$ is half the diameter of the minor diameter, which is applicable for both circular and ellipse shaped objects. Procedure time was defined as the time from incision with the Flushknife until complete removal of the lesion. Proficiency (resec- 
tion speed), defined as square centimeter resected per hour $\left(\mathrm{cm}^{2} / \mathrm{h}\right)$, was calculated. Main outcomes were en bloc and R0 resection rates as well as proficiency and recurrence. The following variables were tested with univariate and multivariate analysis for possible impact on main outcomes: lesion localization, area, Paris type and histologic grade.

\section{ESD training and learning curve}

All procedures were performed by a single experienced colonoscopist (HT) who prior to the study period learned ESD by attending ESD tutorial courses, undertaking animal ex vivo training in Europe and Japan and performing ESD under supervision of Japanese experts. All ESD procedures were grouped consecutively in five chronological time periods with similar numbers of procedures in each period as follows: period 1 (P1) 60 cases, period 2 (P2) 60 cases, period 3 (P3) 60 cases, period 4 (P4) 60 cases, period 5 (P5) 61 cases. This division was decided prior to data processing and statistical computations to minimize bias.

\section{Histological evaluation}

Resected specimens were sectioned serially at 3-mm intervals and embedded for histological examination. The Vienna classification of gastrointestinal neoplasia was used to classify the colorectal neoplasms [27]. Resections were defined as follows; R0 tumor-free vertical and lateral margins, R1 evidence of tumor cells on the vertical or lateral margins, RX margins could not be reliably assessed.

\section{Complications and post-ESD management}

All patients' medical records were scrutinized to detect any complications up to 30 days after ESD. The Clavien-Dindo classification of surgical complications was adopted [28]. Complications were classified as immediate (detected during the procedure) or delayed (detected after ESD). Perforation was defined as defects with visible omentum or other tissue outside the muscle layer detected during the procedure or as free air in the abdomen on image studies or apparent during emergency surgery. Bleeding was defined as immediate hemorrhage causing abortion of the procedure or clinical evidence within 14 days of the procedure. Follow-up was determined by the referring physician, supported by European Society of Gastrointestinal Endoscopy (ESGE) guidelines taking patient wish, age and comorbidity into account [29].

\section{Post-procedural care and need for hospitalization}

Need for hospitalization was determined prior to ESD considering lesion location and size as well as patient age and comorbidity. During the early periods, patients were in general hospitalized if lesions were larger than $5 \mathrm{~cm}$ and/or based on proximal location and/or high age and comorbidities. During the later periods, individuals with rectal lesions and distal colonic lesions were managed as outpatients regardless of lesion size. Patients scheduled as outpatients were hospitalized if needed as evaluated on a case to case basis.

\section{Statistics and ethics}

Data are given as median and range. All data analysis was conducted with SPSS version 22.0 (SPSS Inc., Chicago, Illinois, United States). Categorical variables were compared with the Chisquared test. Linear by linear association was used to evaluate changes in categorical parameters over time. Continuous variables were compared using the one-way Annova test with the Bonferroni-Holm correction. Univariate and multivariate regression analysis were used to determine predictors of main outcomes. $\mathrm{P}$ values $<0.05$ were considered significant. All patients received detailed information prior to the procedure explaining risks of complications and possibility of additional surgery. Informed consent was obtained. Approval by the Regional Ethical Review Board, Lund University (2017/1) was granted prior to the study and ethical principles of the Declaration of Helsinki were followed. All data were coded and patient anonymity was guaranteed.

\section{Results}

\section{Patient and tumor characteristics}

Between January 2013 and November 2017 (59 months), 301 colorectal ESD cases with invasion limited to the mucosa were included and reviewed. 284 cases were large $(>2 \mathrm{~cm})$ non-pedunculated lesions and 17 cases were recurrences. Median age was 72 years (range $35-96$ ) and consisted of 159 males (53\%) and 142 females (47\%). One hundred seventy-three lesions (57\%) were located in the rectum and 128 (43\%) were located in the colon ( $\triangleright$ Table 1 ). Median size was $4 \mathrm{~cm}$ (range $1-12.5$ ) and area $11 \mathrm{~cm}^{2}$ (range $0.8-78.5$ ). Lesion type according to Paris classification and histology are depicted in $>$ Table 1.

\section{ESD performance}

En bloc resection was achieved in 241 out of 301 cases, amounting to an en bloc resection rate of $80 \%$ for the entire period ( Table 2 ). Piecemeal resection was performed in 58 cases (19\%) and ESD was incomplete and aborted in two cases (1\%) ( Table 2 ). R0 resection was accomplished in 207 cases (69\%) and RX and R1 were attained in 83 (27\%) and 11 (4\%) cases, respectively. Median procedural time was 98 min (range $10-588$ ) and median proficiency was $7.2 \mathrm{~cm}^{2} / \mathrm{h}$ (range $0.6-$ 56.4) ( $\triangleright$ Table 2). En bloc and R0 resection rates according to lesion localization was as follows: rectum $87 \%$ and $74 \%$, distal colon $83 \%$ and $64 \%$, proximal colon $54 \%$ and $59 \%$, respectively ( $>$ Table 3 ).

\section{Learning curve}

There was no significant difference in lesion location, macroscopic type and histopathology of the lesions between the five periods. Median lesion area was significantly larger in the fifth period $\left(14.1 \mathrm{~cm}^{2}\right)$ compared to the first period $\left(6.3 \mathrm{~cm}^{2}\right)(P<$ $0.001)$ ( $\triangleright$ Table 1$)$. In addition, ESD proficiency improved from P1 to P3 $-5(P<0.001)$ and from P2 to P3 $-5(P<0.001)$ but there was no significant improvement in proficiency after $\mathrm{P} 3$ ( $\triangleright$ Table 2). Thus, after 120 ESD procedures $(\mathrm{P} 1+\mathrm{P} 2)$ no significant improvement in proficiency was observed. The en bloc re- 
- Table 1 Patient and lesion characteristics.

\begin{tabular}{|c|c|c|c|c|c|c|}
\hline & P1 & P2 & P3 & P4 & P5 & Total \\
\hline $\begin{array}{l}\text { Number of cases } \\
\text { Residual lesions }\end{array}$ & $\begin{array}{l}60 \\
8\end{array}$ & $\begin{array}{l}60 \\
4\end{array}$ & $\begin{array}{l}60 \\
1\end{array}$ & $\begin{array}{l}60 \\
1\end{array}$ & $\begin{array}{l}61 \\
3\end{array}$ & $\begin{array}{l}301 \\
17\end{array}$ \\
\hline Age & $\begin{array}{l}73 \\
(46-96)\end{array}$ & $\begin{array}{l}77 \\
(40-89)\end{array}$ & $\begin{array}{l}72 \\
(40-90)\end{array}$ & $\begin{array}{l}69 \\
(35-90)\end{array}$ & $\begin{array}{l}68 \\
(37-89)\end{array}$ & $\begin{array}{l}72 \\
(35-96)\end{array}$ \\
\hline $\begin{array}{l}\text { Gender } \\
\text { Female } \\
\text { Male }\end{array}$ & $\begin{array}{l}25 \\
35\end{array}$ & $\begin{array}{l}27 \\
33\end{array}$ & $\begin{array}{l}34 \\
26\end{array}$ & $\begin{array}{l}25 \\
35\end{array}$ & $\begin{array}{l}31 \\
30\end{array}$ & $\begin{array}{l}142 \\
159\end{array}$ \\
\hline $\begin{array}{l}\text { Localization } \\
\text { Rectum } \\
\text { Distal colon } \\
\text { Proximal colon }\end{array}$ & $\begin{array}{l}30 \\
14 \\
16\end{array}$ & $\begin{array}{l}32 \\
16 \\
12\end{array}$ & $\begin{array}{l}33 \\
14 \\
13\end{array}$ & $\begin{array}{l}39 \\
12 \\
9\end{array}$ & $\begin{array}{l}39 \\
16 \\
6\end{array}$ & $\begin{array}{l}173(57 \%) \\
72(24 \%) \\
56(19 \%)\end{array}$ \\
\hline $\begin{array}{l}\text { Paris type } \\
\text { Is } \\
\text { lia } \\
\text { Ila/Is }\end{array}$ & $\begin{array}{l}27 \\
30 \\
3\end{array}$ & $\begin{array}{l}22 \\
36 \\
2\end{array}$ & $\begin{array}{l}35 \\
23 \\
2\end{array}$ & $\begin{array}{l}31 \\
24 \\
5\end{array}$ & $\begin{array}{l}33 \\
24 \\
4\end{array}$ & $\begin{array}{l}148 \\
137 \\
16\end{array}$ \\
\hline $\begin{array}{l}\text { Histology } \\
\text { Serrated } \\
\text { Adenoma LGD } 1 \\
\text { Adenoma HGD }\end{array}$ & $\begin{array}{l}1 \\
40 \\
19\end{array}$ & $\begin{array}{l}1 \\
38 \\
21\end{array}$ & $\begin{array}{l}- \\
43 \\
17\end{array}$ & $\begin{array}{l}1 \\
43 \\
16\end{array}$ & $\begin{array}{l}2 \\
38 \\
21\end{array}$ & $\begin{array}{l}5 \\
202 \\
94\end{array}$ \\
\hline $\begin{array}{l}\text { Lesion size } \\
\text { Diameter }(\mathrm{cm})\end{array}$ & $\begin{array}{l}3 \\
(1.5-8)\end{array}$ & $\begin{array}{l}4 \\
(1-8)\end{array}$ & $\begin{array}{l}4 \\
(1.5-10)\end{array}$ & $\begin{array}{l}5 \\
(2-11)\end{array}$ & $\begin{array}{l}5 \\
(2-12.5)\end{array}$ & $\begin{array}{l}4 \\
(1-12.5)\end{array}$ \\
\hline Area $\left(\mathrm{cm}^{2}\right)$ & $\begin{array}{l}6.3 \\
(1.1-44)\end{array}$ & $\begin{array}{l}9.4 \\
(0.8-38)\end{array}$ & $\begin{array}{l}10.6 \\
(1.1-56)\end{array}$ & $\begin{array}{l}13.9 \\
(2.5-69)\end{array}$ & $\begin{array}{l}14.1 \\
(3.1-78)\end{array}$ & $\begin{array}{l}11 \\
(0.8-78)\end{array}$ \\
\hline
\end{tabular}

- Table 2 ESD outcome.

\begin{tabular}{|c|c|c|c|c|c|c|}
\hline & P1 & P2 & P3 & P4 & P5 & Total \\
\hline Number of cases & 60 & 60 & 60 & 60 & 61 & 301 \\
\hline $\begin{array}{l}\text { Resection } \\
\text { En bloc } \\
\text { Piecemeal } \\
\text { Incomplete }\end{array}$ & $\begin{array}{l}36(60 \%) \\
22(37 \%) \\
2(3 \%)\end{array}$ & $\begin{array}{l}45(75 \%) \\
15(25 \%) \\
-\end{array}$ & $\begin{array}{l}49(82 \%) \\
11(18 \%) \\
-\end{array}$ & $\begin{array}{l}51(85 \%) \\
9(15 \%) \\
-\end{array}$ & $\begin{array}{l}60(98 \%) \\
1(3 \%) \\
-\end{array}$ & $\begin{array}{l}241(80 \%) \\
58(19 \%) \\
2(1 \%)\end{array}$ \\
\hline $\begin{array}{l}\text { R0 } \\
\text { R1 } \\
\text { RX }\end{array}$ & $\begin{array}{l}36(60 \%) \\
3(5 \%) \\
21(35 \%)\end{array}$ & $\begin{array}{l}37(62 \%) \\
- \\
23(38 \%)\end{array}$ & $\begin{array}{l}46(76 \%) \\
1(2 \%) \\
13(22 \%)\end{array}$ & $\begin{array}{l}39(65 \%) \\
4(7 \%) \\
17(28 \%)\end{array}$ & $\begin{array}{l}49(80 \%) \\
3(5 \%) \\
9(15 \%)\end{array}$ & $\begin{array}{l}207(69 \%) \\
11(4 \%) \\
83(27 \%)\end{array}$ \\
\hline Procedural time (min) & $\begin{array}{l}133 \\
(19-588)\end{array}$ & $\begin{array}{l}122 \\
(28-260)\end{array}$ & $\begin{array}{l}75 \\
(10-300)\end{array}$ & $\begin{array}{l}78 \\
(16-362)\end{array}$ & $\begin{array}{l}91 \\
(32-312)\end{array}$ & $\begin{array}{l}98 \\
(10-588)\end{array}$ \\
\hline $\begin{array}{l}\text { Proficiency } \\
\left(\mathrm{cm}^{2} / \mathrm{h}\right)\end{array}$ & $\begin{array}{l}3.6 \\
(2.4-10)\end{array}$ & $\begin{array}{l}5.4 \\
(0.6-26)\end{array}$ & $\begin{array}{l}9.6 \\
(0.6-31)\end{array}$ & $\begin{array}{l}10.2 \\
(2.4-35)\end{array}$ & $\begin{array}{l}10.8 \\
(2.4-56)\end{array}$ & $\begin{array}{l}7.2 \\
(0.6-56)\end{array}$ \\
\hline $\begin{array}{l}\text { Hospitalised } \\
\text { Median stay }\end{array}$ & $\begin{array}{l}39(66 \%) \\
1(1-18)\end{array}$ & $\begin{array}{l}26(43 \%) \\
1(1-5)\end{array}$ & $\begin{array}{l}20(33 \%) \\
1(1-4)\end{array}$ & $\begin{array}{l}14(23 \%) \\
1(1-103)\end{array}$ & $\begin{array}{l}14(23 \%) \\
1(1-6)\end{array}$ & $\begin{array}{l}113(38 \%) \\
1(1-103)\end{array}$ \\
\hline
\end{tabular}

section rate improved throughout the periods, starting at $60 \%$ during P1 and gradually increased to $98 \%$ during P5 $(P<0.001)$ ( $\triangleright$ Table 2). R0 resection rate also improved over periods with a temporary decrease between P3 (76\%) and P4 (65\%), however improvement over time tested significant with linear by linear association $(P=0.017)(\triangleright$ Table 2$)$. There was not any signifi- cant trend or difference regarding complication rate between the study periods ( $\triangleright$ Table 4 ). Notably, during P5 there was no significant difference in terms of en bloc and $\mathrm{R} 0$ resection rates according to localization (rectum; en bloc 39/39 (100\%), R0 32/ 39 (82\%), distal colon; en bloc 15/16 (94\%) R0 12/16 (75\%), proximal colon; en bloc 5/6 (83\%), R0 5/6 (83\%). 
- Table 3 ESD outcome according to location.

\begin{tabular}{|c|c|c|c|c|c|c|c|}
\hline & En bloc & RO & $\begin{array}{l}\text { Proficiency } \\
\left(\mathrm{cm}^{2} / \mathrm{h}\right)\end{array}$ & Perforation & $\begin{array}{l}\text { Complication } \\
\text { Bleeding }\end{array}$ & Total & Recurrence \\
\hline $\begin{array}{l}\text { Rectum } \\
N=173\end{array}$ & $\begin{array}{l}150 \\
(87 \%)\end{array}$ & $\begin{array}{l}128 \\
(74 \%)\end{array}$ & $\begin{array}{l}9 \\
0.6-56\end{array}$ & $\begin{array}{l}3 \\
(2 \%)\end{array}$ & $\begin{array}{l}3 \\
(2 \%)\end{array}$ & $\begin{array}{l}6 \\
(4 \%)\end{array}$ & $\begin{array}{l}4 \\
(2 \%)\end{array}$ \\
\hline $\begin{array}{l}\text { Distal Colon } \\
N=72\end{array}$ & $\begin{array}{l}61 \\
(83 \%)\end{array}$ & $\begin{array}{l}46 \\
(64 \%)\end{array}$ & $\begin{array}{l}7.2 \\
0.6-30\end{array}$ & $\begin{array}{l}4 \\
(6 \%)\end{array}$ & $\begin{array}{l}1 \\
(1 \%)\end{array}$ & $\begin{array}{l}5 \\
(7 \%)\end{array}$ & $\begin{array}{l}2 \\
(3 \%)\end{array}$ \\
\hline $\begin{array}{l}\text { Proximal Colon } \\
N=56\end{array}$ & $\begin{array}{l}29 \\
(54 \%)\end{array}$ & $\begin{array}{l}33 \\
(59 \%)\end{array}$ & $\begin{array}{l}4.8 \\
1.2-20\end{array}$ & $\begin{array}{l}10 \\
(18 \%)\end{array}$ & $\begin{array}{l}3 \\
(5 \%)\end{array}$ & $\begin{array}{l}13 \\
(23 \%)\end{array}$ & $\begin{array}{l}1 \\
(2 \%)\end{array}$ \\
\hline
\end{tabular}

- Table4 Complications and follow-up.

\begin{tabular}{|c|c|c|c|c|c|c|}
\hline & P1 & P2 & P3 & P4 & P5 & Total \\
\hline Number of cases & 60 & 60 & 60 & 60 & 61 & 301 \\
\hline $\begin{array}{l}\text { Immediate perforation } \\
\text { Surgery }\end{array}$ & $\begin{array}{l}2 \\
1\end{array}$ & $\begin{array}{l}5 \\
-\end{array}$ & $\begin{array}{l}2 \\
-\end{array}$ & $\begin{array}{l}- \\
-\end{array}$ & $\begin{array}{l}3 \\
-\end{array}$ & $\begin{array}{l}12 \\
1\end{array}$ \\
\hline $\begin{array}{l}\text { Delayed perforation } \\
\text { Surgery }\end{array}$ & $\begin{array}{l}2 \\
1\end{array}$ & $\begin{array}{l}1 \\
1\end{array}$ & - & $\begin{array}{l}2 \\
2\end{array}$ & - & $\begin{array}{l}5 \\
4\end{array}$ \\
\hline $\begin{array}{l}\text { Immediate bleeding } \\
\text { Transfusion } \\
\text { Surgery }\end{array}$ & $\begin{array}{l}1 \\
- \\
-\end{array}$ & $\begin{array}{l}- \\
- \\
-\end{array}$ & $\begin{array}{l}- \\
- \\
-\end{array}$ & $\begin{array}{l}- \\
- \\
-\end{array}$ & $\begin{array}{l}- \\
- \\
-\end{array}$ & $\begin{array}{l}1 \\
- \\
-\end{array}$ \\
\hline $\begin{array}{l}\text { Delayed bleeding } \\
\text { Transfusion } \\
\text { Surgery }\end{array}$ & $\begin{array}{l}- \\
- \\
-\end{array}$ & $\begin{array}{l}- \\
- \\
-\end{array}$ & $\begin{array}{l}- \\
- \\
-\end{array}$ & $\begin{array}{l}5 \\
3 \\
1\end{array}$ & $\begin{array}{l}1 \\
- \\
-\end{array}$ & $\begin{array}{l}6 \\
3 \\
1\end{array}$ \\
\hline $\begin{array}{l}\text { Follow-up } \\
\text { Months } \\
\text { Residual } \\
\text { Planned follow-up }\end{array}$ & $\begin{array}{l}40 \\
22(3-53) \\
3 \\
-\end{array}$ & $\begin{array}{l}50 \\
18(4-36) \\
2 \\
-\end{array}$ & $\begin{array}{l}49 \\
8(3-27) \\
1 \\
1\end{array}$ & $\begin{array}{l}43 \\
9(5-14) \\
1 \\
7\end{array}$ & $\begin{array}{l}22 \\
6(3-10) \\
- \\
39\end{array}$ & $\begin{array}{l}204(68 \%) \\
12(3-53) \\
7(3 \%) \\
47\end{array}$ \\
\hline
\end{tabular}

It was found that lesion location affected en bloc and R0 resection rate and tested significant with both univariate and multivariate analysis with higher rates in rectum $(P<0.001)$ and lower rates in proximal colon $(P<0.001)$ ( $\triangleright$ Table 5). Lesion location also had significant impact on both proficiency and complications with higher proficiency and less complications in the rectum and lower proficiency and more complications in the proximal colon with both univariate and multivariate analysis ( $\triangleright$ Table 5). Moreover, lesion area had negative impact on R0 resection rate testing significant with multivariate analysis ( $\triangleright$ Table 5). Lesion area had also a negative impact on proficiency, which was significant with both univariate and multivariate analysis ( $\triangleright$ Table 5 ). When tested with multivariate analysis, Paris type Is had positive impact $(P=0.004)$ and Paris type Ila had negative impact on proficiency $(P=0.017)$.

\section{Complications}

Complications occurred in 24 patients (8\%) divided into $12 \mathrm{im}$ mediate perforations, five delayed perforations, one immediate bleeding and six delayed bleeds ( $>$ Table 4). Ten of the 11 patients who suffered from delayed complications were inpatients. Thus, eight of the complications were detected during the hospital stay and three patients with hematochezia re- turned to the emergency unit 2, 4 and 11 days after ESD. We experienced two cases of incomplete resection. One was due to a perforation in the left flexure, resulting in emergency surgery and the other was due to a bleed during resection of a rectal lesion, which was managed by use of clips. In total, six patients had emergency surgery $(2 \%, \triangleright$ Table 4$)$ due to a complication (Clavien-Dindo grade IIIb), one patient with a delayed cecal perforation needed intensive care post-surgery (ClavienDindo grade IV). Complications requiring surgical intervention were all located in the proximal colon ( 2 in cecum, 3 in ascending colon, 1 in transverse colon). The remaining 18 complications could be managed conservatively with observation, fasting, antibiotics or blood transfusions in selected cases (Clavien-Dindo II) ( $\$$ Table 4). Complications were more frequent in the proximal colon $(13 / 56,23 \%)$ in comparison to distal coIon $(5 / 72,7 \%)$ and rectum $(6 / 173,4 \%)(P<0.001)(\triangleright$ Table 3$)$.

\section{Follow-up}

Two hundred and four patients (68\%) were followed up endoscopically ( $\triangleright$ Table 4 ). Median follow-up time was 13 months (range $3-53$ ) revealing seven recurrences (3\%) of which four had been resected by piecemeal technique ( $2 \mathrm{R} 1$ and $2 \mathrm{RX}$ ). Two recurrences had been resected en bloc ( $2 \mathrm{RO})$ and one oc- 
Table 5 Factors influencing outcome.

\begin{tabular}{|c|c|c|c|c|}
\hline \multirow[t]{2}{*}{ Variable } & \multicolumn{2}{|l|}{ Univariate } & \multicolumn{2}{|l|}{ Multivariate } \\
\hline & Odds Ratio (95\% Cl) & $P$-value & Odds Ratio $(95 \% \mathrm{Cl})$ & $P$ value \\
\hline \multicolumn{5}{|c|}{ Impact on en bloc resection } \\
\hline $\begin{array}{l}\text { Localization } \\
\text { Rectum } \\
\text { Distal colon } \\
\text { Proximal colon }\end{array}$ & $\begin{array}{l}2.70(1.50-4.84) \\
1.48(0.72-3.03) \\
0.19(0.10-0.35)\end{array}$ & $\begin{array}{l}0.001 \\
0.286 \\
<0.001\end{array}$ & $\begin{array}{l}2.64(1.45-4.80) \\
1.55(0.75-3.24) \\
0.17(0.01-0.34)\end{array}$ & $\begin{array}{l}0.001 \\
0.24 \\
0.001\end{array}$ \\
\hline \multicolumn{5}{|c|}{ Impact on $\mathrm{R} 0$ resection } \\
\hline $\begin{array}{l}\text { Localization } \\
\text { Rectum } \\
\text { Distal colon } \\
\text { Proximal colon }\end{array}$ & $\begin{array}{l}1.91(1.16-3.16) \\
0.82(0.46-1.45) \\
0.47(0.26-0.86)\end{array}$ & $\begin{array}{l}0.010 \\
0.489 \\
0.013\end{array}$ & $\begin{array}{l}2.14(1.27-3.62) \\
0.75(0.41-1.35) \\
0.44(0.23-0.82)\end{array}$ & $\begin{array}{l}0.004 \\
0.332 \\
0.011\end{array}$ \\
\hline Size (Area) & $0.98(0.97-1.00)$ & 0.066 & $0.98(0.96-1.00)$ & 0.04 \\
\hline \multicolumn{5}{|c|}{ Impact on complications } \\
\hline $\begin{array}{l}\text { Localization } \\
\text { Rectum } \\
\text { Distal colon } \\
\text { Proximal colon }\end{array}$ & $\begin{array}{l}0.21(0.06-0.77) \\
2.11(0.67-6.67) \\
2.88(0.90-9.16)\end{array}$ & $\begin{array}{l}0.010 \\
0.195 \\
0.063\end{array}$ & $\begin{array}{l}0.20(0.05-0.78) \\
2.30(0.69-7.67) \\
3.18(0.86-11.78)\end{array}$ & $\begin{array}{l}0.020 \\
0.175 \\
0.083\end{array}$ \\
\hline \multicolumn{5}{|c|}{ Impact on proficiency } \\
\hline & BETA $^{1}$ & $P$-value & BETA $^{1}$ & $P$ value \\
\hline $\begin{array}{l}\text { Localization } \\
\text { Rectum } \\
\text { Distal colon } \\
\text { Proximal colon }\end{array}$ & $\begin{array}{l}0.223 \\
-0.053 \\
-0.224\end{array}$ & $\begin{array}{l}<0.001 \\
0.364 \\
<0.001\end{array}$ & $\begin{array}{l}0.113 \\
-0.020 \\
-0.124\end{array}$ & $\begin{array}{l}0.025 \\
0.695 \\
0.015\end{array}$ \\
\hline $\begin{array}{l}\text { Macroscopic type } \\
\text { Is } \\
\text { lia } \\
\text { Ila/Is }\end{array}$ & $\begin{array}{l}0.060 \\
-0.078 \\
0.038\end{array}$ & $\begin{array}{l}0.302 \\
0.183 \\
0.516\end{array}$ & $\begin{array}{l}0.145 \\
-0.121 \\
-0.046\end{array}$ & $\begin{array}{l}0.004 \\
0.017 \\
0.368\end{array}$ \\
\hline Size (Area) & 0.526 & $<0.001$ & 0.532 & $<0.001$ \\
\hline
\end{tabular}

curred after an incomplete resection in the rectum secondary to bleeding. Three of the recurrences were small and removed by use of biopsy forceps or snare. One recurrence was successfully removed by ESD. Transanal endoscopic microsurgery was used to remove two recurrences in the rectum. One patient with recurrence in the sigmoid colon underwent surgery due to difficult location. One stricture in the rectum was observed and treated successfully with endoscopic dilatation. Forty-seven patients are waiting for endoscopic follow-up ( $>$ Table 4). Three patients underwent resection during emergency surgery and the remaining 47 patients will not be followed up due to patient refusal, high age or aggravating comorbidity.

\section{Hospitalization}

One hundred eighty-eight patients (62\%) were managed as outpatients and 113 patients (38\%) were hospitalized ( $\triangleright$ Table2). Four of the hospitalized patients were scheduled as outpatients but admitted to the hospital for observation after ESD. The rate of hospitalization was higher during the first period $(66 \%)$ in comparison to the fifth period $(23 \%)(P<0.001,>$ Ta- ble 2). One patient with a cecal perforation had additional complications post-surgery necessitating intensive care and represents the upper range of the hospital stay.

\section{Discussion}

ESD is standard treatment of early gastrointestinal neoplasia in Asian countries and recommended by the 2015 ESGE guidelines as a first option to provide en bloc resection with accurate pathologic staging of complex colorectal lesions with high suspicion of limited submucosal invasion [10]. In spite of this, dissemination of ESD in western countries has been slow. One obstacle in the west is the low number of suitable ESD cases in the upper gastrointestinal tract, which constitutes the base for training ESD in Asia [30-31]. Although recent studies suggest that prior gastric ESD is not necessary for learning colorectal ESD [23, 32], problems with limited access of endoscopists proficient in ESD hamper widespread implementation of ESD in western countries. Herein, we present the outcome, complica- 
tions and learning curve on the largest material of colorectal ESD in a specialized western center.

The main purpose of ESD is to remove complex and large neoplasms en bloc to reduce recurrences, provide adequate oncological staging and avoid unnecessary surgery [6]. One recent literature study showed that 1 out of 17 patients undergoing colorectal ESD avoid unnecessary surgery due to superficial invasive cancer [33]. When scrutinizing 29 ESD cases harboring submucosal invasive CRC, published by us previously, we found that 11 out of 12 potentially curable lesions were curative resections. Under ESGE definition [10], the remaining 17 cases were primarily non-curative due to deep submucosal invasion and in these cases ESD served as a staging procedure $[10,24]$. Moreover, in the current study, we found that in 301 patients undergoing colorectal ESD, en bloc and R0 resection rates were $80 \%$ and $69 \%$, respectively. Interestingly, these results are similar to the outcome of resecting malignant colorectal lesions by use of ESD (en bloc $83 \%$, R0 69\%) [24]. Furthermore, this outcome in efficacy is also in line with previous larger series of colorectal ESD in western countries with an en bloc and R0 resection rate ranging between $79 \%$ and $88 \%$ and $63 \%$ and 79 $\%$, respectively $[8-9,22-23]$.It is interesting to note that in the last period of this study, we observed an en bloc rate of 98 $\%$ and $\mathrm{R} 0$ resection rate of $80 \%$, which is compatible with the best centers in Japan $[6,11,32]$. In this context, it is important to note that en bloc and $\mathrm{R} 0$ resection rates were significantly higher in the distal colon and rectum compared to the proximal colon, which is in line with previous reports on colorectal ESD $[9,23,34-35]$, suggesting that ESD in the right colon is far more difficult and associated with longer learning curves compared to ESD in the distal colon and rectum. However, data in the present study and more recently published studies from Europe indicate that ESD in the right colon can safely be implemented although lesions larger than $5 \mathrm{~cm}$ in the right colon is still a challenge for endoscopists proficient in ESD [23]. Moreover, we found that lesion size and Paris type lla negatively influenced en bloc and $\mathrm{R} 0$ resection rate in this study. Thus, localization, size and type of lesions are important factors to consider in programs implementing colorectal ESD.

The question of what is required for an endoscopist to reach proficiency in performing colorectal ESD remains controversial. One arbitrary definition of efficient ESD is an $\mathrm{R} 0$ resection rate of $80 \%[30,36]$. In this study, we found a R0 resection rate of $76 \%$ in period 3 after 120 cases of colorectal ESD. However, this measurement is prone to bias and insecure because it depends on the percentage of colonic versus rectal ESD cases, the size and type of lesions, which influences the efficacy of ESD as shown herein. The increase in size observed in this study (lesion area increased by $224 \%$ between the first and last period) will underestimate the skill development during the learning curve of ESD. Perhaps proficiency, defined as dissection speed, better reflects progress in ESD. Oyama et al. suggested that a dissection speed of $9 \mathrm{~cm}^{2} / \mathrm{h}$ indicates adequate proficiency in colorectal ESD [36]. In the current study, dissection speed increased steeply to $9.6 \mathrm{~cm}^{2} / \mathrm{h}$ after 120 ESD cases and remained above that level to the end of the study, suggesting that adequate proficiency can be reached after 120 cases of colorectal ESD. Notably, this development is also reflected by a gradual increase in en bloc and $\mathrm{R} 0$ resection rate throughout the five periods, which tested significant using linear by linear association. It is also interesting to note that differences in en bloc and $\mathrm{R} 0$ resection rates that were observed between rectal, distal colonic and proximal colonic lesions for the entire period were diminished and non-significant during the last period after $240 \mathrm{ESD}$ procedures, indicating that ESD in the proximal colon should first be attempted when sufficient training and experience with rectal and then distal colonic lesions have been acquired.

Complications such as perforation and bleeding are feared in ESD and one early quality goal in implementation of ESD is to limit the complication rate to less than $10 \%$ [36]. In the current study, we observed 17 perforations and seven cases of bleeding, corresponding to a total complication rate of $8 \%$ and comparable to previous studies from established centers in Japan $[6,30,37]$. It is interesting to note that we found a higher complication rate (13\%) when investigating malignant colorectal lesions resected by using ESD, indicating an increased degree of difficulty when resecting lesions with submucosal invasion [24]. Moreover, there was no sign of reduction in complications in the current study between the different periods which is most likely related to the concomitant increase in lesion size knowing that size of the lesion is an important determinant for risk of ESD complications [6, 35]. The great majority of the complications $(75 \%)$ were managed conservatively but six patients required emergency surgery. It is notable that all cases requiring surgery were located in the proximal colon, underlining the difficulty of performing ESD in the right colon. Indeed, the overall complication rate was significantly higher in the proximal colon compared to the distal colon and rectum in our study, which is in line with previous studies [32,34,38 - 39].

The necessity of hospitalization of colorectal ESD patients is not scientifically proven and unnecessary hospitalization causes increased health care costs. Herein, we observed that the rate of hospitalization decreased from $66 \%$ in the first period down to $23 \%$ in the last period without any increase in complication rate or need for surgery, suggesting that a great majority of ESD procedures can be safely performed as day surgery without hospitalization, given careful patient selection and information. This notion is in line with a recent study showing that 156 out of $171(91 \%)$ colorectal ESD cases could safely and effectively be conducted on an out-patient basis [40]. These findings have significant economic impact by reducing costs associated with colorectal ESD. However, taking the increased risk of complications when resecting proximal lesions in the colon using ESD into account, it might be suggested that these patients should be admitted as inpatients. One reason for implementing ESD is to reduce the number of recurrences by avoiding piecemeal resection of large lesions [10,41-42]. Interestingly, we found seven recurrences in the 204 patients (3\%) that were followed up endoscopically with a median follow-up time of 13 months. Notably, this recurrence rate after ESD is in line with a large recent report from Japan showing 15 recurrences after 390 ESD resections (4\%) [7]. Interestingly, two recurrences occurred after en bloc R0 resections, which might be explained by cells 
released during the procedure that settle in the ESD wound or by incorrect microscopic evaluation. Moreover, one patient required endoscopic dilation of a stricture in the rectum after removal of a lesion covering more than $90 \%$ of circumference. Although risk of developing post-ESD stenosis in upper gastrointestinal lesions is significant [43-45], risk of stricture is negligible in ESD procedures involving less than $90 \%$ of the circumference in the rectum [46-48].

There are certain limitations to our current study. All ESD procedures were exclusively performed by one operator at one specialized single center and it is not known whether such experiences can be directly extrapolated to other institutions. On the other hand, inclusion of a single operator might be an advantage when studying learning curves by circumventing performance variations between different endoscopists. Another limitation is that $16 \%$ of all patients undergoing ESD were not followed up endoscopically for different reasons and the relatively short follow-up time of 13 months impairs conclusions on long-term outcome. In addition, the retrospective nature of the study and lack of randomization against alternative methods, such as piecemeal EMR, limits conclusions about the exact role of ESD in overall management of large and complex colorectal lesions although this was not a primary goal of the current study.

\section{Conclusion}

In conclusion, our data constitute the largest report on colorectal ESD in a western setting and show that the learning curve is steep and ESD can be implemented in western countries at tertiary expert centers, with results comparable to centers in Japan. However, this study also underlines the importance of adequate patient selection to ensure safe implementation of colorectal ESD since larger and proximal lesions were associated with higher risk of complications.

\section{Competing interests}

None

\section{References}

[1] Zauber AG, Winawer SJ, O'Brien M] et al. Colonoscopic polypectomy and long-term prevention of colorectal-cancer deaths. N Engl J Med 2012; 366: 687-696

[2] Ferlitsch M, Moss A, Hassan C et al. Colorectal polypectomy and endoscopic mucosal resection (EMR): European Society of Gastrointestinal Endoscopy (ESGE) Clinical Guideline. Endoscopy 2017; 49: $270-297$

[3] Kudo S. Endoscopic mucosal resection of flat and depressed types of early colorectal cancer. Endoscopy 1993; 25: 455 - 461

[4] Saito Y, Fujii T, Kondo H et al. Endoscopic treatment for laterally spreading tumors in the colon. Endoscopy 2001; 33: 682-686

[5] Arebi N, Swain D, Suzuki N et al. Endoscopic mucosal resection of 161 cases of large sessile or flat colorectal polyps. Scand J Gastroenterol 2007; 42: 859-866
[6] Saito Y, Uraoka T, Yamaguchi Y et al. A prospective, multicenter study of 1111 colorectal endoscopic submucosal dissections (with video). Gastrointest Endosc 2010; 72: 1217-1225

[7] Yamada M, Saito Y, Takamaru H et al. Long-term clinical outcomes of endoscopic submucosal dissection for colorectal neoplasms in 423 cases: a retrospective study. Endoscopy 2017; 49: $233-242$

[8] Probst A, Ebigbo A, Markl B et al. Endoscopic submucosal dissection for early rectal neoplasia: experience from a European center. Endoscopy 2017; 49: 222-232

[9] Sauer M, Hildenbrand R, Oyama T et al. Endoscopic submucosal dissection for flat or sessile colorectal neoplasia > $20 \mathrm{~mm}$ : A European single-center series of 182 cases. Endosc Int Open 2016; 4: E895 - 900

[10] Pimentel-Nunes P, Dinis-Ribeiro M, Ponchon T et al. Endoscopic submucosal dissection: European Society of Gastrointestinal Endoscopy (ESGE) Guideline. Endoscopy 2015; 47: 829-854

[11] Repici A, Hassan C, De Paula PessoaD et al. Efficacy and safety of endoscopic submucosal dissection for colorectal neoplasia: a systematic review. Endoscopy 2012; 44: $137-150$

[12] Gondal G, Grotmol T, Hofstad B et al. Biopsy of colorectal polyps is not adequate for grading of neoplasia. Endoscopy 2005; 37: 1193-1197

[13] Absar MS, Haboubi NY. Colonic neoplastic polyps: biopsy is not efficient to exclude malignancy. The Trafford experience. Tech Coloproctol 2004; 8 Suppl 2: s257-260

[14] Toyonaga T, Man-i M, East JE et al. 1,635 Endoscopic submucosal dissection cases in the esophagus, stomach, and colorectum: complication rates and long-term outcomes. Surg Endosc 2013; 27: 1000 1008

[15] Niimi K, Fujishiro M, Kodashima S et al. Long-term outcomes of endoscopic submucosal dissection for colorectal epithelial neoplasms. Endoscopy 2010; 42: 723-729

[16] Draganov PV, Coman RM, Gotoda T. Training for complex endoscopic procedures: how to incorporate endoscopic submucosal dissection skills in the West? Expert Rev Gastroenterol Hepatol 2014; 8: 119 121

[17] Ma MX, Bourke M]. Endoscopic submucosal dissection in the West: Current status and future directions. Dig Endosc 2018; 30: 310-320

[18] Fuccio L, Hassan C, Ponchon T et al. Clinical outcomes after endoscopic submucosal dissection for colorectal neoplasia: a systematic review and meta-analysis. Gastrointest Endosc 2017; 86: 74- 86 e17

[19] Saito Y, Bhatt A, Matsuda T. Colorectal endoscopic submucosal dissection and its journey to the West. Gastrointest Endosc 2017; 86: $90-92$

[20] Committee AT, Hwang JH, Konda V et al. Endoscopic mucosal resection. Gastrointest Endosc 2015; 82: 215-226

[21] Committee AT, Maple JT, Abu DayyehBK et al. Endoscopic submucosal dissection. Gastrointest Endosc 2015; 81: 1311-1325

[22] Probst A, Golger D, Anthuber M et al. Endoscopic submucosal dissection in large sessile lesions of the rectosigmoid: learning curve in a European center. Endoscopy 2012; 44: 660-667

[23] Spychalski M, Skulimowski A, Dziki A et al. Colorectal endoscopic submucosal dissection (ESD) in the West - when can satisfactory results be obtained? A single-operator learning curve analysis Scand J Gastroenterol 2017; 52: $1442-1452$

[24] Rönnow CF, Elebro J, Toth E et al. Endoscopic submucosal dissection of malignant non-pedunculated colorectal lesions. Endoscopy International Open 2018; 6: E961 - E968

[25] [Anonymous] The Paris endoscopic classification of superficial neoplastic lesions: esophagus, stomach, and colon: November 30 to December 1, 2002. Gastrointest Endosc 2003; 58: S3-43

[26] Thorlacius H, Uedo N, Toth E. Implementation of endoscopic submucosal dissection for early colorectal neoplasms in Sweden. Gastroenterol Res Pract 2013; 2013: 758202 
[27] Dixon MF. Gastrointestinal epithelial neoplasia: Vienna revisited. Gut 2002; 51: $130-131$

[28] Dindo D, Demartines N, Clavien PA. Classification of surgical complications: a new proposal with evaluation in a cohort of 6336 patients and results of a survey. Ann Surg 2004; 240: 205-213

[29] Hassan C, Quintero E, Dumonceau JM et al. Post-polypectomy colonoscopy surveillance: European Society of Gastrointestinal Endoscopy (ESGE) Guideline. Endoscopy 2013; 45: 842 - 851

[30] Hotta K, Oyama T, Shinohara T et al. Learning curve for endoscopic submucosal dissection of large colorectal tumors. Dig Endosc 2010; 22: $302-306$

[31] Sakamoto T, Saito Y, Fukunaga S et al. Learning curve associated with colorectal endoscopic submucosal dissection for endoscopists experienced in gastric endoscopic submucosal dissection. Dis Colon Rectum 2011; 54: 1307 -1312

[32] Shiga H, Ohba R, Matsuhashi T et al. Feasibility of colorectal endoscopic submucosal dissection (ESD) carried out by endoscopists with no or little experience in gastric ESD. Dig Endosc 2017; 29: 58-65

[33] Fuccio L, Repici A, Hassan C et al. Why attempt en bloc resection of non-pedunculated colorectal adenomas? A systematic review of the prevalence of superficial submucosal invasive cancer after endoscopic submucosal dissection Gut 2018; 67: 1464 - 1474

[34] Hori K, Uraoka T, Harada K et al. Predictive factors for technically difficult endoscopic submucosal dissection in the colorectum. Endoscopy 2014; 46: $862-870$

[35] Isomoto $\mathrm{H}$, Nishiyama $\mathrm{H}$, Yamaguchi $\mathrm{N}$ et al. Clinicopathological factors associated with clinical outcomes of endoscopic submucosal dissection for colorectal epithelial neoplasms. Endoscopy 2009; 41: $679-683$

[36] Oyama T, Yahagi N, Ponchon T et al. How to establish endoscopic submucosal dissection in Western countries. World J Gastroenterol 2015; 21: $11209-11220$

[37] Tanaka S, Oka S, Kaneko I et al. Endoscopic submucosal dissection for colorectal neoplasia: possibility of standardization. Gastrointest Endosc 2007; 66: $100-107$
[38] Hayashi N, Tanaka S, Nishiyama S et al. Predictors of incomplete resection and perforation associated with endoscopic submucosal dissection for colorectal tumors. Gastrointest Endosc 2014; 79: 427 435

[39] Imai K, Hotta K, Yamaguchi Y et al. Preoperative indicators of failure of en bloc resection or perforation in colorectal endoscopic submucosal dissection: implications for lesion stratification by technical difficulties during stepwise training. Gastrointest Endosc 2016; 83: 954-962

[40] Ohya T, Marsk R, Pekkari K. Colorectal ESD in day surgery. Surg Endosc 2017; 31: $3690-3695$

[41] Belderbos TD, Leenders M, Moons LM et al. Local recurrence after endoscopic mucosal resection of nonpedunculated colorectal lesions: systematic review and meta-analysis. Endoscopy 2014; 46: 388-402

[42] Oka S, Tanaka S, Saito Y et al. Local recurrence after endoscopic resection for large colorectal neoplasia: a multicenter prospective study in Japan. Am J Gastroenterol 2015; 110: 697-707

[43] Coda S, Oda I, Gotoda T et al. Risk factors for cardiac and pyloric stenosis after endoscopic submucosal dissection, and efficacy of endoscopic balloon dilation treatment. Endoscopy 2009; 41: 421-426

[44] Ono S, Fujishiro M, Niimi K et al. Predictors of postoperative stricture after esophageal endoscopic submucosal dissection for superficial squamous cell neoplasms. Endoscopy 2009; 41: 661-665

[45] Katada C, Muto M, Manabe T et al. Esophageal stenosis after endoscopic mucosal resection of superficial esophageal lesions. Gastrointest Endosc 2003; 57: 165-169

[46] Abe S, Sakamoto T, Takamaru $\mathrm{H}$ et al. Stenosis rates after endoscopic submucosal dissection of large rectal tumors involving greater than three quarters of the luminal circumference. Surg Endosc 2016; 30 : $5459-5464$

[47] Ohara Y, Toyonaga T, Tanaka S et al. Risk of stricture after endoscopic submucosal dissection for large rectal neoplasms. Endoscopy 2016; 48: $62-70$

[48] Hayashi T, Kudo SE, Miyachi H et al. Management and risk factor of stenosis after endoscopic submucosal dissection for colorectal neoplasms. Gastrointest Endosc 2017; 86: 358-369

\section{CORRECTION}

Carl-Fredrik Rönnow, Noriya Uedo, Ervin Toth et al. Endoscopic submucosal dissection of 301 large colorectal neoplasias: outcome and learning curve from a specialized center in Europe

Endoscopy International Open 2018; 06: E1340-E1348. DOI: 10.1055/a-0733-3668

In the above mentioned article table 3 was corrected. 